Life in Debt 



\section{Life in Debt}

Times of Care and Violence

in Neoliberal Chile

Clara Han

甲

UNIVERSITY OF CALIFORNIA PRESS

Berkeley • Los Angeles • London 
University of California Press, one of the most distinguished university presses in the United States, enriches lives around the world by advancing scholarship in the humanities, social sciences, and natural sciences. Its activities are supported by the UC Press Foundation and by philanthropic contributions from individuals and institutions. For more information, visit www.ucpress.edu.

University of California Press

Berkeley and Los Angeles, California

University of California Press, Ltd.

London, England

(C) 2012 by The Regents of the University of California

Library of Congress Cataloging-in-Publication Data

Han, Clara, 1975-

Life in debt : times of care and violence in neoliberal Chile / Clara Han.

p. $\mathrm{cm}$.

Includes bibliographical references and index.

ISBN 978-0-520-27209-5 (cloth : alk. paper) ISBN 978-0-520-272IO-I (pbk. : alk. paper)

I. Chile-Social policy-2 Ist century. 2. ChileEconomic policy-2 Ist century. 3. Political violence-Chile. 4. Neoliberalism-Social aspects-Chile.

I. Title.

HN293.5.H36 $20 \mathrm{I} 2$

$320.60983-\mathrm{dc} 23$

2012001902

Manufactured in the United States of America

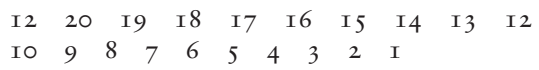

In keeping with a commitment to support environmentally responsible and sustainable printing practices, UC Press has printed this book on 50-pound Enterprise, a $30 \%$ post-consumer-waste, recycled, deinked fiber that is processed chlorine-free. It is acid-free and meets all ANSI/NISO (Z 39.48) requirements. 
For Mom and Dad

For Mike, Alyse, Andy

For Paty

For Maarten 
This page intentionally left blank 